\title{
Muslim Women Managing Women's Shelters: Somaya, the Muslimwoman and Religion as Resource
}

\section{Pia Karlsson Minganti}

To cite this article: Pia Karlsson Minganti (2015) Muslim Women Managing Women's Shelters: Somaya, the Muslimwoman and Religion as Resource, NORA - Nordic Journal of Feminist and Gender Research, 23:2, 93-108, DOI: 10.1080/08038740.2014.935744

To link to this article: http://dx.doi.org/10.1080/08038740.2014.935744

曲 Published online: 21 Aug 2014.

Submit your article to this journal $\pi$

Џll Article views: 228

Q View related articles $₫$

View Crossmark data $\nearrow$ 


\title{
Muslim Women Managing Women's Shelters: Somaya, the Muslimwoman and Religion as Resource
}

\author{
PIA KARLSSON MINGANTI \\ Department of Ethnology, History of Religions and Gender Studies, Stockholm University, \\ Stockholm, Sweden
}

\begin{abstract}
This article focuses on Sisters' Shelter Somaya in Sweden, an organization unique in its claim to be a women's shelter by and for Muslim women, and in its combining of Islamic and secular feminisms. Examining the organization's self-presentations, the author argues that there is, however, an ongoing shift from an emphasis on its Muslim profile to a dissolution of the very same. Looking into potential loss in the process (for clients, activists, allies, and feminism at large), the analysis draws on current research on anti-Muslim intolerance and normative secularism. The concept of the "Muslimwoman" is employed to illustrate the stereotyping that continuously associates Muslim women with "victims" inhabiting shelters rather than capable "managers". Intersectionality is pointed at as an emic strategy adopted by Somaya to overcome division, but also critically analysed as a consensus-creating signifier that hinders diversity. Thus, the article raises the increasingly important issue of the relationship between religion, gender, and feminism in the post-secular turn, and the author calls for critical self-reflection and creative affirmation in the interaction with heterogeneous others.
\end{abstract}

\section{Introduction}

In today's Europe, there are many women's organizations that deal with violence against women at the intersection of gender, religion, and "race"/ethnicity (e.g. Terrafem in Sweden and Southall Black Sisters in the United Kingdom). However, it is rarely the case that shelters for abused women are initiated and run by Muslim women who officially claim their activities to be Islamic.

A common pattern is that organizations are established to represent Muslim women and their rights (e.g. Amina Muslim Women's Resource Centre in the United Kingdom, or Associazione Donne Musulmane d'Italia in Italy), while refuge facilities are offered by secular women's shelters. Another common pattern is for organizations to offer both types of services, but targeting "ethnic", "black", 
"immigrant", or "minority" women, thus not explicitly claiming to be established by and for "Muslim" women (Nyhagen Predelli \& Halsaa 2012: 8).

Hence, this article focuses on a rather unique example - an organization in Sweden called the Sisters' Shelter Somaya. ${ }^{1}$ Founded in 1998, it originally presented itself as a Muslim women's shelter by and for Muslim women (Lindberg 1999). However, by drawing on Somaya's public self-presentations from its opening to the present, the article aims to examine a shift from this emphasis on a Muslim profile towards the dissolving of public references to Islam and Muslim identity. This analytical focus on an ambivalent process of self-definition will open up space for reflections on the relationship between religious diversity and feminism.

I will analyze the shift in relation to four strands that I distinguish as relevant influences in the process. While briefly introducing them here, I will also further elaborate the theoretical concepts involved as they appear in the analysis.

The first strand concerns Somaya's explicit introduction of intersectionality as a cross-boundary approach to its activists, ${ }^{2}$ clients, and allies. I will look into emic expressions of motivations behind this move, but will also analyze it in terms of the critical review of intersectionality as a "consensus-creating signifier", which has enabled an "all-inclusive feminism" that "conceals fruitful and necessary conflicts within feminism" (Carbin \& Edenheim 2013: 233-234).

The second strand concerns the growing anti-Muslim intolerance and the construction of Islam as a politicized and dangerous field (Hervik 2011; Berglund 2013). In this context, the making of religion and gender are intertwined so that "equality agendas of feminisms are projected onto the Nordic nation states as if these are inherently gender-equal in their character" (Stoltz \& Hvenegård-Lassen 2013: 245; see also Hübinette \& Lundström 2011; Keskinen 2012; Andreassen 2013), while Muslim women are represented as victims in need of help to become "liberated" from their particular familial, cultural, and religious attachments (Jacobsen \& Stenvoll 2010; Bracke \& Fadil 2012: 54).

To cast further light on this assimilationist tendency confronting Somaya, the third strand concerns the development of "normative secularism" (Braidotti 2006: 80) that is based on a "sacred narrative of (European) secular progress" (Woodhead 2009: 12) and results in a polarized construction of "good" (secular) and "bad" (religious) Muslims (Maira 2009). I will take inspiration from the processual intersectional concepts of "dissolution" and "saturation", as developed by Staunæs (2003: 107) and Zhao (2013: 206), in order to argue that the category of religion has subsequently become dissolved from Somaya's agenda, which has instead become saturated by matters of secularity. Again, I will look into emic expressions of this process in Somaya's self-presentations, but also relate it to feminist interactions in the wider society, and hence claim that the secular needs to engage self-critically with the religious, not only the other way around (Woodhead 2009: 18). This is particularly important, as feminist philosopher Rosi Braidotti points out, since "an automatic and unreflective brand of normative secularism runs the risk of becoming complicitous with xenophobia and racism" (Braidotti 2006: 80).

Finally I will pinpoint the fact that the dissolving of Somaya's Muslim profile is actually a matter of publicly dissociating religion as a resource for Somaya and its activists, while continuously reinforcing it as an identity marker for the help-seeking 
women. With the help of Miriam Cooke's concept of the "Muslimwoman" (2008), I will illustrate how this situation can be reviewed in terms of the minoritization and victimization of Muslim women (Nyhagen Predelli \& Halsaa 2012), with consequences for their recognition as agents and potential managers.

These four strands of research have a close bearing on mainstream Western feminism, which is generally known as secular but is increasingly becoming involved in the rethinking of standpoints about religion (Reilly 2011; Midden 2012). It is my wish that this investigation of the ambivalent transformation of Somaya's selfpresentations will generate reflection, within Somaya and beyond, on what is at stake when the Islamic religion and Muslim identity are dissolved as a potential resource for feminist struggle.

The material used in this study is based on Somaya's self-presentations, which are investigated as social practices that are informed by and constitutive of power relations. These self-presentations have been retrieved from the organization's official website, Somaya.se, and its Facebook page, as well as from some activists' own text productions and verbal presentations on television and radio. Furthermore, there are a few representations of Somaya disseminated through the reports of governmental and non-governmental organizations, academic bachelor theses, and journalistic articles. No high-level academic publications on the Sisters' Shelter Somaya exist as yet.

My own background is within ethnology and particularly research among activists in Muslim youth organizations (Karlsson Minganti 2007, 2011). During my fieldworks I have been exposed to information about Somaya and have occasionally met with Somaya activists, although formal observations and interviews with them fell beyond the scope of those projects. Additional material is, however, present in the shape of field notes from the organization's early years, more precisely from cofounder Irina Widin's presentation of Somaya at the 18th Conference of the Islamic Association in Sweden (Stockholm, 3 April 1999) and from co-founder Karima Lindberg's presentation at a weekend course for Muslim youth (Stockholm, 7-8 October 2000). In addition, I conducted a telephone interview (4 April 2013) with Susanne Namaani, who was Somaya's organization manager from September 2007 to July 2013, and an email exchange with current organization manager Anna-Karin Rybeck (September 2013).

Hence, the material compiled for this study does not make up the basis for any analysis of everyday practice and negotiation. Neither does it lend itself to precise periodization of the shift in Somaya's profile, or any determination of the influence of particular activists. But it is appropriate for the following in-depth analysis, which is intended to outline a transformation process and rethink the relationship between religious diversity and feminism.

\section{Muslim profile — combining Islamic and secular feminisms}

The Sisters' Shelter Somaya was established in 1998 by a group of women in a suburb of Stockholm that had many inhabitants with Muslim and foreign backgrounds. The founders were themselves Muslims: some immigrants, some converts to Islam. Already involved in assisting female victims of domestic violence at a grassroots level, 
they saw a need to register a formal organization that acknowledged their experiences of linguistic and cultural misunderstandings as well as prejudicial treatment at "conventional" women's centres. Many resented being met with the presumption that they needed to leave their religion and assimilate with the non-Muslim majority (Lindberg 1999; Sonnius 2002; Ücler 2007; Somaya 2014a).

Somaya publicly declared itself to contribute with competence in the Swedish legal and welfare system as well as in various languages, including Swedish. Moreover, the organization affirmed that it offered a shelter where violence against women was not presented as a particularly "Muslim problem" rooted in Islam. For instance, cofounder Karima Lindberg presented the newly established Sisters' Shelter Somaya in the then-important Swedish Islamic periodical Salaam (Otterbeck 2000) in the following way:

Acts such as wife-beating, honour killing, genital mutilation etc. are not compatible with Islam. It is sad that knowledge about Islam is so poor both among Muslims and non-Muslims that this fact needs to be pointed out at all. (Lindberg 1999: 6) ${ }^{3}$

Hence, Somaya presented itself as an organization that offers women the possibility of maintaining their faith while challenging gender-based violence: "A woman who comes to us does not want to get rid of God; she wants to get rid of her husband" (Namaani in Alakangas 2012). Such a quotation represents a clear challenge to the discourse, widespread in today's Europe, that Muslim women need to be liberated from their particular cultural and religious attachments (Bracke \& Fadil 2012: 54).

In challenging this assimilationist discourse, Somaya has engaged in both Islamic and secular feminisms. The term Islamic feminism is highly contested (Bahi 2011; Midden 2012) but broadly refers to a discourse on women's rights that is constructed within an Islamic paradigm (Badran 2002). Various contemporary Islamic revivalist movements present women with the opportunity to re-read Islamic texts and choose reflexively which interpretations to adhere to and disseminate to others (Bano \& Kalmbach 2011; Karlsson Minganti 2011). Many women, Somaya activists among them, critically consider the possibility that some interpretations result from androcentric readings. In order to counteract such bias, they circulate references that instead reflect women's interests and evoke women as role models. In fact, the Sisters' Shelter Somaya is named after the historical figure of Somaya Bint Khayat, who is considered to be one of the original followers of the prophet Muhammed, the seventh person to embrace Islam, and its very first martyr.

With the basic methodology of ijtihad (independent analysis of religious sources) and tafsir (interpretation of the Qur'an), Muslim women (and men) challenge patriarchal cultural patterns as well as traditionalist interpretations that both produce and legitimize these patterns. This methodology is discernible, for instance, in Lindberg's early presentation (mentioned above) of Somaya for the predominantly Muslim readers of Salaam:

Of all the excuses used by abusers in order to disclaim responsibility, probably the worst is using Islam to legitimize one's criminal behaviour. By focusing on 
rituals and disregarding the content and spirit of Islam, they even use Qur'anic verses to justify their sick need for control and power. If the wife has enough courage to oppose such un-Islamic living, the man often misinterprets another Qur'anic verse and uses it as an excuse to abuse her. Abusive men completely disregard Islam's teachings on goodness, love, mercy and respect for others. Also they do not care about the good example of the prophet Muhammed (peace be upon him), who never beat a woman and was extremely kind and goodhearted to his family. (Lindberg 1999: 6)

Below is yet another example of how an original co-founder of Somaya, Monjia Sonnius, confirms the re-reading of Islamic sources as a valid strategy against genderbased violence:
A Muslim women's shelter is actually an absurdity since violence against women is forbidden in Islam. If someone uses the Qur'an as a means of oppression, the staff of Somaya can refute this behaviour by reading what is written in the Qur'an and how the prophet Muhammed explains the word of God. They can also clarify to the women their rights according to Islam. (Sonnius 2002: n.p.; see also Forum Syd et al. 2002: 21)

From my analysis of Somaya's early self-presentations, I distinguish an ambition to be appreciated as an environment where Islam stands as an ethos and frame of reference, and women do not have to worry about breaking with dietary habits or dress codes. It presents as a shelter where the absence of pork meat and the presence of hijabs is the normality, and where the Qur'an is confirmed as being compatible with feminism. Former organization manager Susanne Namaani confirms that this impression was also valid during her employment period from September 2007 to July 2013.

We listen to women, affirm that they have experienced violence, and confirm that it is not because of their religion. ... It is common knowledge that when people are in crisis, they need something to hold on to. For many of these women it is their faith, but it now only remains as a narrow thread. Somaya helps them to hold onto this narrow thread. (Interview Namaani, 4 April 2013)

Although openly problematizing the perceived lack of cultural and religious sensitivity within "conventional" shelters, Somaya has teamed up with various Swedish governmental and non-governmental organizations. As early as 1999, Somaya became a member of the secular feminist Swedish Association of Women's Shelters and Young Women's Empowerment Centres (Sveriges Kvinno- och Tjejjourers Riksförbund, SKR). SKR is one of two major umbrella organizations in Sweden that work to provide protection and guidance for female victims of domestic violence and the prevention of violence against women.

In this way, Somaya and SKR allowed for collaboration, and for the Somaya activists to try out combinations of Islamic and secular feminist ideas. This is not a self-evident position considering the initial suspicion towards Somaya that was 
harboured by various women's organization (Larsson 2007; Ücler 2007; interview Namaani, 4 April 2013). In their study of majority-minority relations in contemporary women's movements in Norway, Spain, and the United Kingdom, Line Nyhagen Predelli and Beatrice Halsaa point out two typical representations of minoritized women by majoritized actors. The first is the perception that "minoritised women's problems are mainly rooted in 'culture', and minoritised women are regarded as being in need of help from majoritised women, rather than being seen as equal partners in women's movements" (2012: 262). Such a representation does not leave much potential for strategic alliance or collaboration between the two categories.

The second type of perception presented by Predelli and Halsaa is that "minoritised women's problems are rooted mostly in racist and discriminatory practices within majority (and minoritised) society, and also that minoritised and majoritised women's problems are caused by gender-based inequalities which cut across different cultures" (2012: 262). This approach contains the potential for cooperation and alliance, and was embodied early on by Somaya and SKR. In the next section, this cross-boundary approach will be further explored as part of a gradual shift in Somaya's self-presentations from a women's shelter run by and for Muslim women to the emphasis on intersectionality.

\section{Toning down the Muslim profile—emphasizing intersectionality}

From the beginning, Somaya defined itself as a religiously and politically independent organization, open to women of all backgrounds and faiths. However, the debate over the notion of Somaya as a mainly "Muslim women's shelter" runs like a thread through the organization's history. The original statute stated that activists "should as far as possible be of different ethnic origins and thereby competent in several languages, and Muslims". In 2007 this declaration was changed to: "preferably Muslims or sharing the values of the Sisters' Shelter Somaya" (Ücler 2007: 35-36). This decision was taken after discussions about whether the exclusion of women of other faiths from functioning as Somaya activists could be perceived as a deterrent and discriminatory, both for those seeking help and for those who aspire to work as activists (Ücler 2007: 35-36). With this acknowledgement of the actual heterogeneity of the people involved in Somaya, the shelter's public selfpresentations are becoming more articulate in the vocabulary of intersectionality, as for instance in the following two statements which I first retrieved from Somaya's website in 2012 and which are still there at the time of writing:

Today the Sisters' Shelter Somaya is open to all women regardless of religion, ethnicity or background. We believe that we, by being a part of the sisterhood, can counteract men's violence against women and honour-related violence. (Somaya 2014a)

One must explain and understand honour-related oppression from an intersectional perspective; where gender, class, ethnicity and socio-economic conditions, among other things, are included. (Somaya 2014b) 
From this self-declared intersectional standpoint, Somaya collaborates with both secular and religious actors. The interactions include Somaya criticizing some Muslim actors' lack of practical initiatives to prevent violence against women, for instance the failure to recognize women's divorces from their abusive husbands or to report abuse to the police (Karlsson Minganti 2007: 224; 2012). Even in its early stages, Somaya took a clear position that women and their children need to be taken out of violent situations; that is, out of their families and homes in cases where their lives or health are at risk.

Sometimes it is enough for a frustrated man to talk with an imam. But if he systematically controls and abuses a woman, her situation is desperate and her children's too. Then they urgently need to get away from him. It could happen that they live together again one day, but this cannot be a prioritized issue for us at Somaya. (Field notes from co-founder Irina Widin's presentation of Somaya at the 18th Conference of the Islamic Association in Sweden, Stockholm, 3 April 1999)

Declaring itself to be a shelter for women who seek refuge from violent family members means challenging the conservative patriarchal position that prioritizes the continuity of family ties at all costs. By threatening such a patriarchal position, Somaya has become a target of anti-feminist resistance: "Exactly as the Swedish women's shelters were initially met with distrust, the Sisters' Shelter Somaya has been accused of splitting up Muslim families and inciting divorce" (Sonnius 2002: n.p.).

However, the development of an intersectional agenda, with its emphasis on all women's subjection under cross-boundary patriarchal oppressions, has simultaneously smoothed Somaya's interactions with Muslim communities. It dismantles the culturalized/racialized view of women's oppression as a particularly "Muslim problem", and eases the fear among many Muslims that openly talking about violence within their communities might "put wind in the sails of racists" (Lindberg 1999: 8). Such concern is not without foundation; the impact of the rhetoric of Muslim women's oppression for assimilatory or anti-Muslim/anti-immigration action is well documented in academic publications, in Sweden and abroad (Cato \& Otterbeck 2011; Hervik 2011; Hübinette \& Lundström 2011; Allen \& Guru 2012; Chakraborti \& Zempi 2012; Keskinen 2012).

Hence, in analysing Somaya's public self-presentations, I claim that the profile of a women's shelter with an intersectional agenda was implicitly there from the start, and gradually developed into an explicit standpoint. I also claim that this happened both out of consideration for the clients' heterogeneous backgrounds and as a crossboundary strategy to aid interaction with various Muslim and non-Muslim actors. However, since the growing emphasis on intersectionality coincided with a deemphasizing of its initial Muslim profile, I will further examine the influence on Somaya's self-presentations of the positioning of religion, and particularly Islam, in Swedish society. 


\section{Normative secularism-dissolving religion as a resource}

The de-emphasis of Islamic references becomes even more evident in Somaya's statutes of 2012, in which the requirements for enrolling no longer include the word "Muslim" (Somaya 2014c). In August 2013, Somaya employed its first non-Muslim organization manager, and the word Islam is now decidedly absent from Somaya's official website. The organization self-defines as "the first women's shelter in the Nordic countries that has both a gender and ethnicity perspective" (Somaya 2014a). Nothing is mentioned about the unique religious perspective that was there at the beginning. Taken together, these moves can be read as signs, not only of the deemphasizing, but also of the dissolving (Zhao 2013: 206) of references to the categories of Islam and Muslimness - a process worth noting and reflecting upon.

The Sisters' Shelter Somaya emerged during a time of broad societal drives against gender-based violence in Sweden at the end of the 1990s. At that time, the Swedish Government adopted a critical feminist perspective which defines men's violence against women as an expression of structural inequality between men and women, and acknowledged battered women as victims of crime. Various educational and opinion-forming campaigns were launched, and funding for national women's organizations was increased. Somaya was born out of, and incorporated into, this wave of action and knowledge production, and became further strengthened by the increasing drives against so-called honour-related violence at the beginning of the 2000s (Government Offices of Sweden 2007; Modée \& Bohlin 2009; Modée \& Larsson-Thörnberg 2009).

Over the years, Somaya has gone from being seen as an obscure Muslim/ immigrant women's organization to a widely celebrated contributor to Swedish society. This increased recognition has become manifest in several awards, such as the prestigious Anna Lindh Memorial Prize. In 2008, the Swedish National Board for Youth Affairs (Ungdomsstyrelsen) was commissioned by the Government to survey the prevalence of arranged marriages against the will of one party. Somaya was invited to collaborate. In 2010, the Government commissioned an official report on increased protection against forced marriages (SOU 2012: 35). Somaya was invited to comment on this report and subsequently recommended the criminalization of forced marriages (Somaya 2014d).

Sweden has a tradition of co-operation between women's organizations and the welfare state. Political scientist Helga Hernes has introduced the notion of feminism from below and above (1987), "denoting the political mobilisation of women and women's organisations on the one hand, and an active strategy by the state to invite women's organisations to take part in policy formation and implementation processes on the other" (Nyhagen Predelli \& Halsaa 2012: 81). The Swedish state has supported Somaya's mobilization from below as a valuable part of the drives against gender-based violence. Moreover, the state has invited Somaya to participate in commenting on arranged marriages; that is, in the active implementation of policies from above. However, as stressed by Lina Nyhagen Predelli and Beatrice Halsaa, "state or institutional feminism [is] an arena where 'boundary-making processes' in recognition struggles take place" (2012: 84), and such struggles, they claim, have tended to result in the production of hegemonic representations of women's identities 
and the marginalization of minoritized women. Thus, a crucial question is: Under what conditions is Somaya considered an acceptable partner to invite for cooperation?

As to this, I see it pertinent to question how religion is positioned in Somaya's official agenda. In an evaluation of Somaya by the Stockholm County Administrative Board (Länsstyrelsen $i$ Stockholms län) in 2006, the assurance is given that Somaya's "activities are not missionary, hence its particular expertise is suitable also for non-practicing Muslims as well as women of other religious backgrounds" (Jemteborn \& Pilar Reyes 2006: 110). The demand for a "nonmissionary" approach appears sensible to the wide range of women looking for support from a women's shelter, but let us articulate this question: How would Somaya be perceived if its approach were deemed "missionary"? Or, if it persistently self-defined as primarily by and for Muslim women?

Presenting oneself or one's organization as religious is not a neutral act in contemporary Sweden. Public discourse is dominated by the association of religion with values fundamentally opposed to modernity, equality, freedom, and democracy (Lövheim \& Axner 2011). In particular, religion expressed in public is seen as a threat to modern society. As immigration has led to the growing visibility of religion, most notably Islam, Muslims have become stigmatized as the ultimate threat to "secular Europe", also in countries less secularized than Sweden in terms of the importance of religion in the public sphere (Salih 2009).

In the construction of Muslims as a threat to secular society, Islam is portrayed as an unchangeable monolith, and the variety of attitudes to the religion is largely overlooked. Similarly, "secularism remains an unmarked term-like 'male' or 'white' - the taken for granted, the unquestioned standpoint of truth" (Woodhead 2009: 17-18). Sociologist of religion Linda Woodhead relates this common-sense position to an influential "European narrative of secular progress" (Woodhead 2009: 12-13; see also Reilly 2011). According to this narrative, Europe has moved from a pre-modern state of oppression connected with religion to a more enlightened state of modernity characterized by freedom and other supposedly secular values. Feminist philosopher Rosi Braidotti warns that a failure to recognize the historical specificity of this narrative runs the risk of turning it into a form of "normative secularism" that brings "European feminism close to that 'cultural racism' that Stuart Hall and black migrant women so eloquently denounce" (Braidotti 2006: 80-81).

In fact, the contemporary political situation, particularly after 11 September 2001, has triggered a wave of anti-Muslim intolerance across Europe and the world. In this context, constructions of religion have become intertwined with constructions of gender in the global discourse about "the war on terror" and "bringing 'democracy" and 'human rights,' particularly 'women's rights,' to regions that presumably need to catch up with Western modernity" (Maira 2009: 631). This rhetoric produces two dichotomous modes of expressing cultural citizenship for Muslims in the West that anthropologist Sunaina Maira calls "good" and "bad" Muslim citizenship (Maira 2009: 633). While "bad" Muslims are denoted as religious fanatics, "good" Muslim citizens are distinguished as secular.

In this context, many Muslims feel it hazardous publicly to use Islamic terminology and symbols, regardless of how their personal attitudes to the religion 
would be defined on a spectrum between religious and secular (Jonker \& Amiraux 2006: 11; Aspling \& Djärv 2013: 55-59; Berglund 2013). For instance, when asked to explain her faith in a journal interview, former organization manager of Somaya, Susanne Namaani, chose to respond with the Islamic term jihad, but only after hesitation, saying that her answer could easily be misunderstood: "Jihad means "for the sake of God' and not 'holy war'. For me every day and every hour here at Somaya means jihad" (Namaani in Alakangas 2012; see also Karlsson Minganti 2011: 381). Individual Muslims' explanations are often drowned by the Islam-equals-violence rhetoric, and Namaani's hesitation is shared by many.

Hence, I suggest that the self-presentations of the Sisters' Shelter Somaya have been altered so as to avoid, and perhaps ultimately dissolve, explicit references to Islam. As discussed above, this move can be understood as an act of inclusion and solidarity that opens up the organization to women from all kinds of backgroundsas clients, activists, and allies. Yet, it can simultaneously be read as a sign of antiMuslim/Islam pressures and the saturation (Staunæs 2003: 107) of Somaya's feminist subject position with normative secularism.

In the next section I will argue that this process involves the dissolution of religion as a resource from Somaya's public self-presentations, with particular regard to its activists, while at the same time religion is reinforced as an identity marker of the help-seeking women. Hence, I will also discuss how this development implies the risk of reproducing Muslim women as victims, and the failure to recognize Somaya as a unique example of Muslim women as managers.

\section{Reproducing Muslim women as victims}

Miriam Cooke, professor of Asian and Middle Eastern Studies, has introduced the neologism Muslimwoman to explain how Muslim women, and particularly Islamic feminists, work to change those conditions that justify the persistence of the image of Muslim women as passive victims (Cooke 2008). When she fuses the words Muslim and woman, she draws attention to the contemporary practice of collapsing religion and gender into a singular identity: "So extreme is the concern with Muslim women today that veiled, and even unveiled, women are no longer thought of as individuals: collectively they have become the Muslimwoman" (Cooke 2008: 91).

This identification is tied to growing Islamophobia, which triggers the construction of boundaries between "us" and "them", "insider" and "outsider". The Muslimwoman represents such a boundary between two major forces (presented as ideal types in a Weberian sense). On the one hand, gender-conservative political "Islamists" deprive women of individuality and agency by naming them cultural custodians and standard-bearers for the Muslim ummah (community, nation, worldwide society). On the other hand, "neo-Orientalists" ascribe the Muslimwoman to Muslim women by erasing their diversity and taking them to represent "Islamic oppression" and everything negative associated with the religion and its followers. These two dominant forces share the goal of managing Muslim women: "At the same time that Islamists vie for control of women's bodies, neo-Orientalists bleat their compassion for the "poor' Muslimwoman" (Cooke 2008: 93). Consequently, Muslim 
women are unlikely to be associated with agency, such as being the managers of women's shelters.

Recent public representations of Somaya provide suitable examples of how unreflective normative secularism results in a "neo-Oriental" reproduction of the image of Muslim women as passive victims. For instance, in a PowerPoint presentation, initially produced by Somaya for an interdisciplinary event on psychotrauma and now available online (Somaya 2013), the concept of religion appears only once: in the expression "religious views", under the headline "vulnerability", and in connection with two images of dark-haired, dark-eyed women. One has her mouth covered by a plaster, the other's cheek is wet with tears. Matching a typical representation of the Oriental/Muslimwoman victim (AbuLughod 2013), these images are juxtaposed with a picture of young, smiling women and $\mathrm{men}^{4}$ of different skin colour who are dressed in short-sleeved and sleeveless tops under the headline "11 persons are working at Somaya". Displayed like this, Somaya activists become associated with the emblematic dress code of a free and happy secular individual, and are distanced from the enveloping clothes of many Muslim women, who are instead linked to "vulnerability" caused by "religious views".

Furthermore, at the beginning of 2014 various actors both inside and outside Somaya expressed criticism of the organization's choice to collaborate with the wellknown human rights activist Sara Mohammad. Mohammad is widely praised for her work against honour-related violence, but she is also criticized for equating this violence with Islam. During this crisis of confidence, the then president of the board, Sara Saadouni, participated in a programme broadcast by the Internet-based television channel Budskapet.tv (Budskapet.tv 2014). There she announced that she had been replaced on the job and expressed her concern about developments that may lead to Muslim women becoming a minority on both the board and in the organization's personnel and target group. She also expressed worries that the Somaya milieu, known for its sensitivity to religious women's needs, is changing into a context that allows the breaking of taboos, such as pork meat and dogs, in consideration of other involved persons' preferences (Budskapet.tv 2014).

Taken together, these recent representations of Somaya can be interpreted as a reinforcement of the victimization and minoritization of Muslim women, now even from within the organization. Simultaneously, these representations bring into public view the ongoing tensions within Somaya; the dissolving of Islam as an explicit resource for feminist work is proving to be a subject of criticism and contestation.

\section{Conclusion}

This article draws critical attention to the increasingly important issue of the relationship between religion, gender, and feminism. More and more feminist critics are involving themselves in challenging both the "religious" versus "secular" binary and the underlying assumptions of "secular feminism". Secularization as an inevitable and uniform process is no longer tenable. Many women see religion as an important part of their lives, and an increasing number strive to combine their religious beliefs with feminist ideas. 
The hitherto understudied organization Sisters' Shelter Somaya provides a suitable example of such a cross-boundary feminist approach. In fact, it offers a rather unique example in that it self-presents as having been established both by and for Muslim women (while open to clients and colleagues from various backgrounds). However, an analysis of Somaya's public self-presentations reveals a gradual suspension of this particular Muslim profile and the development of a secular framework with an emphasis on intersectionality.

I have examined the motivations behind this move and found expressions of a felt need to deal with the actual heterogeneity among the people involved in Somaya (clients, activists, and allies). Also, I have found pressures to deal with the normative notion of the secular society as woman-friendly, in contrast to Islam, which is seen as an inherently oppressive and violent religion. In an ambiguous situation like this, intersectionality can be seen as a common language that promises to overcome division. Yet, such an aim to create consensus runs the risk of being dictated by a majority and foreclosing divergent views. Hence, I call for critical reflection on what values might be lost in the interrelated process of dissolving Somaya's Muslim profile.

The fading of religion as resource, and the minoritization of observant Muslim women even within the organization, mean that women seeking help may lose the opportunity to find an environment they can trust to be "Islamic". Added to this, Muslim communities, including male-dominated formal Muslim organizations, may lose a partner in their work against gender-related violence that communicates from an Islamic frame of reference and refrains from equating Islam with violence. Muslim organizations in Sweden are currently under pressure to produce impeccable selfrepresentations with regard to gender equality. While their shortcomings are scrutinized, I see a lack of understanding of their complex conditions. These communities comprise members from a multitude of ethnic, social, economic, and denominational backgrounds. Some are third-generation citizens; others came to Sweden just days ago. Serving such a diverse community is more than a matter of religious sermons, but involves voluntary social work, including in the area of gender violence. Somaya activists are involved in reflecting upon feminism in such a context. Therefore, I would regard the dissolving of the link to mosques and other Muslim organizations, and the neglecting of these as platforms for ongoing negotiations on gender and violence, as a loss.

With regard to Somaya activists, I have demonstrated that the de-emphasis, and even dissolution, of the organization's Muslim profile is happening in parallel with the reinforcement of the clients' Muslim identity. I have also demonstrated that this move carries the risk of reproducing the image of Muslim women as passive victims, while obscuring Somaya as a unique example of Muslim women managers who make use of Islam as a resource. Failing to see Muslim women as capable activists implies a loss of alternative feminist voices, both within and outside Somaya. This is particularly troublesome for Muslim women, who need scope to take control of the Muslimwoman stereotype. The more Muslim women are able to represent themselves, the more control they will have over its deconstruction and transformation. Among these are feminist-oriented women who, across the alleged Islam-secular divide, are taking part in extending the space for the reinterpretation of gender and religion. 
Hence, by offering contextual insights in this article, I hope to motivate the creation of space for all feminist actors openly to express their views. This includes the various activists in Somaya who, in their unique organization, during 15 years of (internal and external) struggles, have accumulated cutting-edge competence in one of the most intricate human rights issues of today: that of "women's rights" and "freedom of religion".

\section{Acknowledgements}

This article was made possible by support from The Swedish Research Council [grant number 2009-867; 2009-1345]. An early version was presented at the panel "Changing Citizenship in the Context of Migration: New Women's Movements and Everyday Practice" at the 3rd European Conference on Politics and Gender in Barcelona (Spain), 21-23 March 2013. I thank the organizers and participants for their feedback. I also wish to thank the two anonymous reviewers and the editors of NORA who helped to refine my analysis through their insightful comments.

\footnotetext{
Notes

${ }^{1}$ In Swedish: Systerjouren Somaya. Since 29 April 2012, the official name has been "Somaya kvinno- och tjejjour" [Somaya women's and girls' shelter], but the previous label is still used in English presentations. Somaya currently presents itself as an organization with 14 employees with different backgrounds in religion and education (e.g. social work, behavioural science, and psychology). Together with a large number of volunteers the group represents over 30 languages. Somaya provides telephone guidance and protected housing (with places for nine women and eleven children at any one time). Children are recognized as crime victims and are included in the programme with special attention to their needs. A section for young women covers age-relevant issues, such as pressures surrounding sexuality and marriage. In addition, guidance is offered for relatives, colleagues, and friends of female victims of gender violence, as well as lectures, courses, and interviews for various actors in state institutions, NGOs, and the media (Somaya.se; Somaya 2014e).

${ }^{2}$ The term "activist" is here intended to include both employed staff and volunteers.

${ }^{3}$ All translations from Swedish into English in this article are by the author.

${ }^{4}$ In 2009 the statutes of Somaya were revised so that men could become full members of the organization and its board.
}

\section{References}

Abu-Lughod, Lila (2013) Do Muslim Women Need Saving? (Harvard: Harvard University Press).

Alakangas, Anna-Maria (2012) De vill inte bli av med Gud utan sin man [They do not want to get rid of God but of their husband], Tro \& Politik, 3 September.

Allen, Chris \& Guru, Surinder (2012) Between political fad and political empowerment: A critical evaluation of the National Muslim Women's Advisory Group (NMWAG) and governmental processes of engaging Muslim women, Sociological Research Online, 17(3), p. 17. Available at http:// www.socresonline.org.uk/17/3/17.html (accessed 9 May 2014).

Andreassen, Rikke (2013) Muslim women and interracial intimacies, Nordic Journal of Migration Research, 3(3), pp. 117-125.

Aspling, Fredrik \& Djärv, Carina (2013) Hatbrott 2012. Statistik över självrapporterad utsatthet för hatbrott och polisanmälningar med identifierade hatbrottsmotiv. Rapport 16 (Stockholm: Brottsförebyggande rådet).

Bano, Masooda \& Kalmbach, Hilary (Eds) (2011) Women, Leadership and Mosques: Changes in Contemporary Islamic Authority (Leiden: Brill).

Badran, Margot (2002) Islamic feminism: What's in a name? Al-Ahram Weekly Online, 569, pp. 17-23. 
Bahi, Riham (2011) Islamic and Secular Feminisms: Two Discourses Mobilized for Gender Justice. EUI Working Papers RSCAS 2011/25 (San Domenico di Fiesole: European University Institute). Available at: http://cadmus.eui.eu/bitstream/handle/1814/17294/RSCAS_2011_25_rev.pdf (accessed 28 Feb 2014).

Berglund, Jenny (2013) Islamic identity and its role in the lives of young Swedish Muslims, Contemporary Islam, 7(2), pp. 207-227.

Bracke, Sarah \& Fadil, Nadia (2012) "Is the headscarf oppressive or emancipatory?" Field notes from the multicultural debate, Religion and Gender, 2(1), pp. 35-56.

Braidotti, Rosi (2006) Transpositions: On Nomadic Ethics (Cambridge: Polity Press).

Budskapet.tv (2014) Kvinnojouren Somaya och dess samarbete med Sara Mohammad [The Sisters' Shelter Somaya and its collaboration with Sara Mohammad]. Broadcast 12 Feb 2014. Available at: http:// www.budskapet.tv/arkiv/ (accessed 28 Feb 2014).

Cato, Johan \& Otterbeck, Jonas (2011) Aktivt medborgarskap bland muslimer [Active citizenship among Muslims], in: Pieter Bevelander, Christian Fernández \& Anders Hellström (Eds) Vägar till medborgarskap, pp. 71-86 (Lund: Arkiv).

Carbin, Maria \& Edenheim, Sara (2013) The intersectional turn in feminist theory: A dream of a common language? NORA-Nordic Journal of Feminist and Gender Research, 20(3), pp. 233-248.

Chakraborti, Neil \& Zempi, Irene (2012) The veil under attack: Gendered dimensions of Islamophobic victimization, International Review of Victimology, 18(3), pp. 269-284.

Cooke, Miriam (2008) Deploying the Muslimwoman, Journal of Feminist Studies in Religion, 24(1), pp. $91-99$.

Forum Syd (in cooperation with Föreningen för Utvecklingsfrågor FUF, Kvinnoforum, Frivilligorganisationernas fond för mänskliga rättigheter, Svenska UMIFEM-kommittén, Riksförbundet för Sexuell Upplysning RFSU and Rädda Barnen) (2002) Våld i hederns namn. Rapport från en seminarieserie (Stockholm).

Government Offices of Sweden (2007) Action Plan for Combating Men's Violence against Women, Violence and Oppression in the Name of Honour and Violence in Same-Sex Relationships (Stockholm: Riksdagen).

Hernes, Helga (1987) Welfare State and Woman Power: Essays in State Feminism (Oslo: Norwegian University Press).

Hervik, Peter (2011) The Annoying Difference: The Emergence of Danish Neonationalism, Neoracism and Populism in the Post-1989 World (New York and Oxford: Berghahn Books).

Hübinette, Tobias \& Lundström, Catrin (2011) Sweden after the recent election: The double-binding power of Swedish whiteness through the mourning of the loss of "Old Sweden" and the passing of "Good Sweden", NORA - Nordic Journal of Feminist and Gender Research, 19(1), pp. 42-52.

Jacobsen, Christine M. \& Stenvoll, Dag (2010) Muslim women and foreign prostitutes: Victim discourse, subjectivity, and governance, Social Politics: International Studies in Gender, State and Society, 17(3), pp. $270-294$.

Jemteborn, Annika \& Pilar Reyes, Maria (2006) Insatser mot hedersrelaterat våld: En utvärdering av projekten 2005 (Stockholm: Länsstyrelsen in Stockholms län).

Jonker, Gerdien \& Amiraux, Valérie (Eds) (2006) Politics of Visibility: Young Muslims in European Public Spaces (Bielefeld: transcript).

Karlsson Minganti, Pia (2012) Ibland ger moskén skydd till slagna kvinnor när samhället svikit [Sometimes the mosque gives protection to abused women when society has failed], SVT Debatt, 16 May. Available at: http://www.svt.se/opinion/ibland-ger-mosken-skydd-till-slagna-kvinnor-nar-samhalletsvikit (accessed 4 Aug 2014).

Karlsson Minganti, Pia (2011) Challenging from within: Youth associations and female leadership in Swedish mosques, in: Masooda Bano \& Hilary Kalmbach (Eds) Women, Leadership and Mosques: Changes in Contemporary Islamic Authority (Leiden: Brill).

Karlsson Minganti, Pia (2007, 2014) Muslima: Islamisk väckelse och unga kvinnors förhandlingar om genus $i$ det samtida Sverige [Islamic revival and young women's negotiations of gender in contemporary Sweden] (Stockholm: Carlsson).

Keskinen, Suvi (2012) Limits to speech? The racialised politics of gendered violence in Denmark and Finland, Journal of Intercultural Studies, 33(3), pp. 261-274. 
Larsson, Göran (2007) Muslims in the EU: City Report: Sweden: Preliminary Research Report and Literature Survey (New York: Open Society Institute).

Lindberg, Karima (1999) Kvinnomisshandel och Systerjouren Somaya - en muslimsk kvinnojour [Gender violence and the Sister's Shelter Somaya - a Muslim women's shelter], Salaam, 5, pp. 5-8.

Lövheim, Mia \& Axner, Martha (2011) Halal-TV: Negotiating the place of religion in Swedish public discourse, Nordic Journal of Religion and Society, 24(1), pp. 57-74.

Maira, Sunaina (2009) "Good" and "bad" Muslim citizens: Feminists, terrorists, and U.S. orientalisms, Feminist Studies, 35(3), pp. 631-656.

Midden, Eva (2012) Feminism and cultural and religious diversity in Opzij: An analysis of the discourse of a Dutch feminist magazine, European Journal of Women's Studies, 19(2), pp. 219-235.

Modée, Lisa \& Bohlin, Ingrid (2009) Gift mot sin vilja [Married against her will] (Stockholm: Ungdomsstyrelsen).

Modée, Lisa \& Larsson-Thörnberg, Jonas (2009) Tjejjourerna - en växande kraft: Insatser mot hedersrelaterat våld och förtryck [The girls' shelters - a growing force: Efforts against honour-related violence and oppression] (Stockholm: Ungdomsstyrelsen).

Nyhagen Predelli, Line \& Halsaa, Beatrice (2012) Majority-Minority Relations in Contemporary Women's Movements: Strategic Sisterhood (Basingstoke: Palgrave Macmillan).

Otterbeck, Jonas (2000) Islam på svenska. Tidskriften Salaam och islams globalisering [Islam in Swedish: The journal Salaam and the globalisation of Islam] (Lund: Lund University).

Reilly, Niamh (2011) Rethinking the interplay of feminism and secularism in a neo-secular age, Feminist Review, 97(1), pp. 5-31.

Salih, Ruba (2009) Muslim women, fragmented secularism and the construction of interconnected 'publics' in Italy, Social Anthropology, 17(4), pp. 409-423.

Somaya (2014a) Somayas historia [The history of Somaya]. Available at: http:/www.somaya.se/om-oss/ somayas-historia-5936115 (accessed 26 Feb 2014).

Somaya (2014b) Tjejjour [Girls' shelter]. Available at: http://www.somaya.se/start/kvinno-tjejjour/tjejjour5816997 (accessed 26 Feb 2014).

Somaya (2014c) Somaya stadgar 2012 [Somaya statutes 2012]. Available at: http://www.somaya.se/omoss/om-f\%C3\%B6reningen-5936119 (accessed 26 Feb 2014).

Somaya (2014d) Kriminalisera barn- och tvångsäktenskap [Criminalise child marriage and forced marriage]. Available at: http://www.somaya.se/start/om-v\%C3\%A5ld /hedersrelaterat-v $\% \mathrm{C} 3 \%$ A5ld-14002923 (accessed 26 Feb 2014).

Somaya (2014e) Verksamhetsberättelse 2012 [Annual report 2012]. Available at: http://www.somaya.se/ start/om-v\%C3\%A5ld/hedersrelaterat-v\%C3\%A5ld-14002923 (accessed 28 Feb 2014).

Somaya (2013) Våra värderingar - påverkar de vårt möte? [Our values - do they influence our encounter?]. PowerPoint presentation, Traumadagen, Stockholm, September 5, 2013. Available at: http:// traumadagen.se/file/anna-karin-rybeck-vara-varderingar-paverkar-de-vart-mote.pdf (accessed 17 Oct 2013).

Sonnius, Monjia Manai (2002) Andakt [Worship]. January 21. Personal website. Available at: http://hem. passagen.se/mson/Islam/texter/Andakter.htm (accessed 17 Oct 2013).

SOU 2012:35 Stärkt skydd mot tvångsäktenskap och barnäktenskap [Enhanced protection against forced marriage and child marriage]. Stockholm: Fritzes.

Staunæs, Dorthe (2003) Where have all the subjects gone? Bringing together the concepts of intersectionality and subjectification, NORA - Nordic Journal of Feminist and Gender Research, 11(2), pp. 101-110.

Stoltz, Pauline \& Hvenegård-Lassen, Kirsten (2013) NORA 20th Anniversary (1993-2013) Special issue on "Feminist Resistance-Resistance to Feminism", NORA - Nordic Journal of Feminist and Gender Research, 21(4), pp. 245-248.

Ücler, Heidi Esma (2007) Du skall väl vara hemma och föda barn? En fallstudie av systerjouren Somaya, en kvinno- och tjejjoursverksamhet som drivs av största delen muslimska kvinnor [Shouldn't you be home giving birth to children? A case study of the Sisters' Shelter Somaya, a women's and girls' shelter mainly run by Muslim women], (Bachelor Thesis) (Gothenburg: Gothenburg University, Department of Social Work). 
Woodhead, Linda (2009) The Muslim veil controversy and European values, Swedish Missiological Themes, 97(1), pp. 89-105. Available at: www.eprints.lancs.ac.uk/39909/1/Veil_and_Values_-SMT. doc (accessed 17 Oct 2013).

Zhao, Yan (2013) Intersectionality, the production of difference and Norwegian transnational adoptees' identity work, NORA - Nordic Journal of Feminist and Gender Research, 21(3), pp. 201-217.

Pia Karlsson Minganti is a researcher and associate professor of ethnology at Stockholm University, and a guest researcher at the University of Bologna and the Uppsala Religion and Society Research Centre, where she is also a member of the Impact of Religion excellence programme. Her research fields include young Muslims in Europe, transnational migration, religious pluralism, and cultural transformations of identity and gender relations. Among her recent publications are: Muslima. Islamisk väckelse och unga kvinnors förhandlingar om genus $i$ det samtida Sverige [Muslima: Islamic Revival and Young Women's Negotiations of Gender in Contemporary Sweden] (Carlsson 2007, 2014) and "Challenging from Within: Youth Associations and Female Leadership in Swedish Mosques", in: Masooda Bano and Hilary Kalmbach (Eds), Women, Leadership and Mosques: Changes in Contemporary Islamic Authority (Brill 2011). 